JOURNAL OF SECURITY AND SUSTAINABILITY ISSUES

ISSN 2029-7017 print/ISSN 2029-7025 online

2019 June Volume 8 Number 4

http://doi.org/10.9770/jssi.2019.8.4(21)

Scopus ${ }^{\circ}$

\title{
ACCUMULATION AND FULFILMENT OF THE HUMAN CAPITAL POTENTIAL IN ORDER TO STRENGTHEN THE ECONOMIC SECURITY
}

\author{
Nataliya Demidova', Olena Akilina², Mariya Kirzhetska ${ }^{3}$, Volodymyr Lagovskyi ${ }^{4}$, Svetlana Besarab ${ }^{5}$ \\ ${ }^{1}$ Federal State-Funded Educational Institution of Higher Education Don State Technical University, Ukraine \\ 2* Borys Grinchenko Kyiv University, 18/2 Bulvarno-Kudriavska Str, Kyiv, 04053, Ukraine \\ ${ }^{3}$ National university "Lviv Polytechnic”, 12 Bandera str., Lviv, Ukraine \\ ${ }^{4}$ University of the State Fiscal Service of Ukraine, 31, Universitetskaya street, Kyiv region, Irpin, Ukraine \\ ${ }^{5}$ Kyiv National Economic University, 54/1 Prospect Peremogy, Kyiv, Ukraine \\ E-mail: ${ }^{2 *}$ koaduep@gmail.com
}

Received 25 November 2018; accepted 28 April 2019; published 30 June 2019

\begin{abstract}
The research work considers the essence and features of human capital accumulation at the company level in order to provide its economic security. The main components of intellectual capital in the format of human, organizational and customer capital have been studied. The managerial rationality of using the method of direct evaluation of intellectual capital and the method based on market capitalization has been proved. Both methods give the greatest organizational effect in providing economic security. The empirical study of using the quantitative assessment of human capital of a machine-building company has been carried out in order to strengthen its economic security.
\end{abstract}

Keywords: economic security; human capital; sustainable development; intellectual capital; evaluation method; human resources (HR); company staff

Reference to this paper should be made as follows: Demidova, N.; Akilina, O.; Kirzhetska, M.; Lagovskyi, V.; Besarab, S. 2019. Accumulation and fulfilment of the human capital potential in order to strengthen the economic security, Journal of Security and Sustainability Issues 8(4): 801-813. http://doi.org/10.9770/jssi.2019.8.4(21)

JEL Classifications: J24

\section{Introduction}

The current state of economic development is under the influence of unpredictable internal and external factors that have different nature and mechanism of influence on the companies. This requires urgent search for ways in order to strengthen the level of their economic security, first of all by increasing the efficiency of using current human capital and releasing existing labor potential. In order to solve this problem, first of all, one has to intensify the processes of acquiring key competencies and to form effective mechanisms for managing the process of accumulation of the overall potential of companies. This will make it possible to compensate for the uncertain influence of external factors.

The questions of human capital potential formation and economic security is widely illustrated in a number of scientific papers (Ahammad, 2017; Garfield, 2014; Laursen, and Foss, 2003; Martin and Hetrick, 2006; Meyer, et al. 2010; Mosley, 2007; William, 2016; Kumar et al., 2019). The following problems have been, and continue to be, the most urgent alongside with others - these are ensuring 
stable competitive positions of domestic companies and searching for ways in order to increase the efficiency of their activities on the basis of intensive use of internal resources, especially in the field of personnel.

The human capital, together with a system of motivating factors, is exactly the most important source of ensuring promising competitiveness of companies and increasing the level of economic security.

This is the very reason why the high level of relevance of the research is devoted to expanding the spectrum of theoretical and methodological foundations of strengthening and positive qualitative transformation of the economic security of business structures.

\section{Concept of human capital}

The concept of human capital (HC) undergoes rather radical changes in its own development. Initially, the authors of HC concept were committed to more precisely explain and promote the idea of equal role with material resources of intangible non-separable assets from person in creating a cumulative social product, to justify the validity of such an approach, to show its theoretical and practical outputs instead of giving a concise definition of the new category introduced by them (Hamid and Yahya, 2011; Makedon et al. 2019; Arribas, I.; Espinós-Vañó, M. D.; García, F.; Tamosiuniene, R., 2019). Human capital is formed by means of investments in a person, among which one can distinguish education, training, health care, migration, and the search for information on prices and profits. The concept of human capital has considerably expanded in economic theory. Recent calculations made by experts from the World Bank include its consumer expenditure. These are family expenditures on food, clothing, housing, education, health, culture, as well as government expenditures on these goals. The canonical HC definition does not exist until now, as well as there is no unity of opinions about meaningful content of this concept.

It is quite obviously that the $\mathrm{HC}$ is the foundation of the company's intellectual capital and a part of its economic security, since all other components are derivatives of human capital. Today HC is interpreted as one of the components of a more general category, called the intellectual capital. Therefore, in terms of ensuring sustainable development and strengthening economic security, one should analyze these aspects. So the concept of intellectual capital includes at least three main components: 1) human capital; 2) organizational capital; 3) customer capital.

The components of intellectual capital corresponds to the following definitions, which are the generalization of most of the world's scientific sources (Lievens et al. 2007; Markoulli, et al. 2017; Schuler, and Jackson, 2005; Zhou, J., Wang, et al. 2017; Sagiyeva et al., 2019).

Human Capital is a set of individual knowledge, experience, skills and abilities of company staff and its capability to perceive changes.

Organizational capital is an internal structure of the organization; it is based on processes, strategies, concepts, patents, methodologies, databases, trade secrets, brands, etc. It contains the intellectual property of the organization (patents, trademarks, copyrights, service marks, design rights, etc.) and its infrastructure. The organizational capital does not change in the conditions of the termination of individual employees.

Customer capital is the loyalty of customers, their continuity and reliability, the efficiency of the chain of promotion of goods.

In addition to the given selection of the main components of human capital, there are several additional components, into which the main components can be divided. According to the materials published by the specialists of the Swedish company Scania, these components are defined as follows: 
Structural capital. It is what remains in the organization when employees being carriers of human capital are returning home. Structural capital, for example, includes databases, consumer lists, guides, trademarks, and organizational structures.

Intellectual capital. It consists of structural capital and human capital, takes into account the possibility of future income in terms of human contribution, its capability to continuously create and generate even more value.

Human capital is already interpreted in this approach as the aggregate amount of investment in education, the capability and future employee. It may also be considered as the competence of the employee, his/hers capability to communicate and create value for the customer.

Organizational capital is considered in accordance with this approach as systematized and gathered together competency plus systems that allow realize the company's capability to innovate, as well as organizational capacity to create capital. It consists of process, cultural and innovation capital.

Innovation capital. The capability to upgrade a company is expressed in the form of intellectual property; in other words, it is protected by commercial law, as well as by other intangible assets and values, such as work practices and trade secrets.

Process capital. It is the aggregate value of processes, which both create and do not create value.

It should be noted that human capital includes such an important parameter as the capability of employees to perceive changes. This human capital parameter becomes the most important one in terms both of intense dynamic processes in the economic system and the need to provide economic security.

\section{Evaluation of human capital of the company}

During sufficient period, human capital has been measured solely by qualitative approaches that determine the availability and degree of manifestation of such qualitative characteristics as the capability to think extraordinary, use skills and experience combined with intuition, etc.

In particular, the mentioned qualitative characteristics are an integral part of the intellectual capital of the company. The contribution of staff to overall results is determined in such directions (Grip de et al. 2001; Macky, and Boxall, 2007; Drobyazko S., 2018a,b; Prakash, Garg, 2019):

- contribution to the development of new scientific directions;

- contribution to the increase of company profits;

- contribution to the development of relations with customers;

- contribution to the coordination of the divisions;

- contribution to the successful implementation of linear functions.

In terms of the expert approach, one evaluates both the qualitative characteristics of a particular employee and the set of properties of human potential. With greater objectivity of this method, weighting factors are used. The calculation procedure includes three stages:

1. Determination of key indicators that identify the employee contribution to the intellectual capital of the company.

2. Determination of sampling weights (significance factors) for each indicator, based on how often each indicator is manifested by the employee who is being tested.

3. Determination of the rating scale in order to assess each indicator.

The results are then analyzed and the average rating for each employee is determined. These values are compared with the reference ones, obtained by the empirical method (by summing all the points for all qualitative 
indicators). An expert approach involves various modifications and is a necessary component of the assessment of human capital.

There are plenty of quantitative methods in order to measure and assess intellectual assets of companies, each of which has certain advantages and disadvantages. None of these methods can be considered as universal one; consequentially, it has led some powerful companies to develop their own techniques that can more accurately assess their real intellectual potential. Nevertheless, all existing methods can be divided into two major classes: 1. method of direct evaluation of intellectual capital (direct intellectual capital method, DIC) (Lee, and Hong, 2002);

2. method based on market capitalization (market capitalization method, MCM) (Whatishumanresource.com, 2017; Masood, O.; Tvaronavičienè, M.; Javaria, K., 2019).

The method of direct evaluation of intellectual capital is reduced to the direct measurement of the value of intangible assets; all their components (together or separately) are evaluated in order to make this.

The method based on market capitalization determines the difference between market capitalization of the company and the value of its shareholders' securities.

The most commonly used methods belonging to the first group are:

- Sveiby's Intangible Assets Monitor (IAM), which was developed in the early 90's of the last century;

- navigator of intangible assets of Scania AB (Sweden), which was offered at the end of the 90s of the last century.

Sveiby's Intangible Assets Monitor (Myloni, et al. 2006; Korauš, A.; Gombár, M.; Kelemen, P.; Backa, S., 2019) considers three categories of non-material categories to be evaluated (Table 1):

1. competence of staff (capability to act in different situations);

2. internal structure (unstructured, "raw" information; databases, knowledge bases; tools for data and knowledge mining; technological and business processes; patents and rights, etc.);

3. external structure (trademarks, brands, relations with customers and suppliers).

Table 1. Sveiby's Intangible Assets Monitor

\begin{tabular}{|c|c|c|c|}
\hline Indicators & Competences & Internal structure & External structure \\
\hline Growth and upgrade & Number of years of study & Investing in research and development & Growth of the market share \\
\hline Efficiency of use & Added value per employee & Percentage of support staff & Profit from one customer \\
\hline Stability & Professional labour turnover & Support labour turnover & Reorders \\
\hline
\end{tabular}

Source: Myloni, et al. 2006

According to the Sveiby's approach, three characteristics of each element are defined: their growth and upgrade, efficiency of use and stability. According to this approach, the system has five categories:

1) finances (traditional financial indicators are analyzed);

2) customers (type of customers, duration of relationships, reliability);

3) process (it is analyzed how the organization uses its own information and technological resources);

4) future upgrade and development of the organization;

5) staff of the organization (it is measured by the productivity of intellectual work).

\section{Case: Measurement of human capital of Scania AB}

Let us consider the possibility to assess the intellectual capital for the Swedish company Scania AB. Let us distribute employees to their capability to create an added value that drives buyers to prefer the products of this company (Table 2). 
Table 2. Distribution of Scania AB employees according to their capability to create an added value

\begin{tabular}{|c|c|}
\hline $\begin{array}{c}\text { Hard to replace } \\
\text { Low added value } \\
\bullet \text { staff members }\end{array}$ & $\begin{array}{c}\text { Hard to replace } \\
\text { High added value } \\
\bullet \text { purchasing managers } \\
\bullet \text { sales managers }\end{array}$ \\
\hline $\begin{array}{c}\text { Easy to replace } \\
\text { Low added value } \\
\text { cleaning woman }\end{array}$ & Easy to replace \\
High added value \\
$\bullet$ drivers \\
$\bullet$ accountant
\end{tabular}

Source: Designed by the authors

In the lower left quadrant of the Table 2, unskilled or semi-skilled labor is displayed. The company does need such people, but success does not depend on them. Dozens of people will respond to the vacancy announcement, and the term of study itself is minimal.

In the left upper quadrant, there are people who have mastered more complex operations. This is skilled warehouse staff for Scania $\mathrm{AB}$ who knows the entire range of products. It is difficult to find a replacement for them, because it is necessary not only to know the product in the field of electrical products, but also to understand it, and in order to make it, one has to obtain either a special education or to possess relevant experience. The task of management with respect to these people is to fill their activities with new information content (Štiglic, 2017).

Employees placed in the lower right quadrant of the Table 2, earn a profit, providing high quality products for the company; these are people with special skills and abilities. For example, timely and quality delivery of goods to customers plays a huge role in shaping the image for Scania AB, however good drivers can be found on the job market quite easily.

And, finally, the experts are placed in the upper right quadrant of the Table 2; these are purchasing and sales managers being irreplaceable specialists. The human capital of Scania AB is realized precisely in people of the right upper quadrant of the Table 2, namely those whose talents multiplied by experience make it possible to conclude agreements and contracts favorable for the company, to establish relations with buyers and suppliers, to create additional value, to encourage customers to buy the goods exactly at the company «Scania $\mathrm{AB}$ ». The higher the saturation of business with human capital, the higher the percentage of highly profitable work done by people who are difficult to replace - the more valuable their services are and the more successful the company increases its competitive advantages and stimulates the strengthening of economic security.

Describing the human capital of Scania AB, we will plot a table with the characteristics of human capital for each manager, evaluating them on a 10 -point scale in the Table 3.

Table 3. Evaluation of human capital of Scania AB

\begin{tabular}{|c|c|c|c|c|c|}
\hline \multicolumn{2}{|r|}{ Category of employees } & $\mathrm{T}$ & $\mathrm{H}$ & G & $\mathrm{C}$ \\
\hline 1 & Education & 5 & 9 & 9 & 9 \\
\hline 2 & Experience in this specialty & 8 & 7 & 10 & 9 \\
\hline 3 & Training at the expense of the company & 2 & 0 & 2 & 4 \\
\hline 4 & Average salary & 8 & 8 & 9 & 9 \\
\hline 5 & Attitude of employees to work (devotion to the job) & 5 & 8 & 9 & 4 \\
\hline 6 & Implementation of the annual plan & 7 & 10 & 10 & 3 \\
\hline 7 & Satisfaction with the job, occupied position & 6 & 9 & 8 & 7 \\
\hline 8 & Satisfaction with the remuneration system & 6 & 8 & 6 & 8 \\
\hline
\end{tabular}

Source: Residents and social processes (2017), calculation by authors 
The abbreviation T, $\mathrm{H}, \mathrm{G}$ and $\mathrm{C}$ denotes the following categories of employees:

$\mathrm{T}$ - main and auxiliary workers, technical staff;

$\mathrm{H}$ - middle and low level of managers;

$\mathrm{G}$ - top management;

$\mathrm{C}$ - engineering and technical staff.

Let us plot the results obtained on the graph (Fig. 1) in the form of irregular polygons.

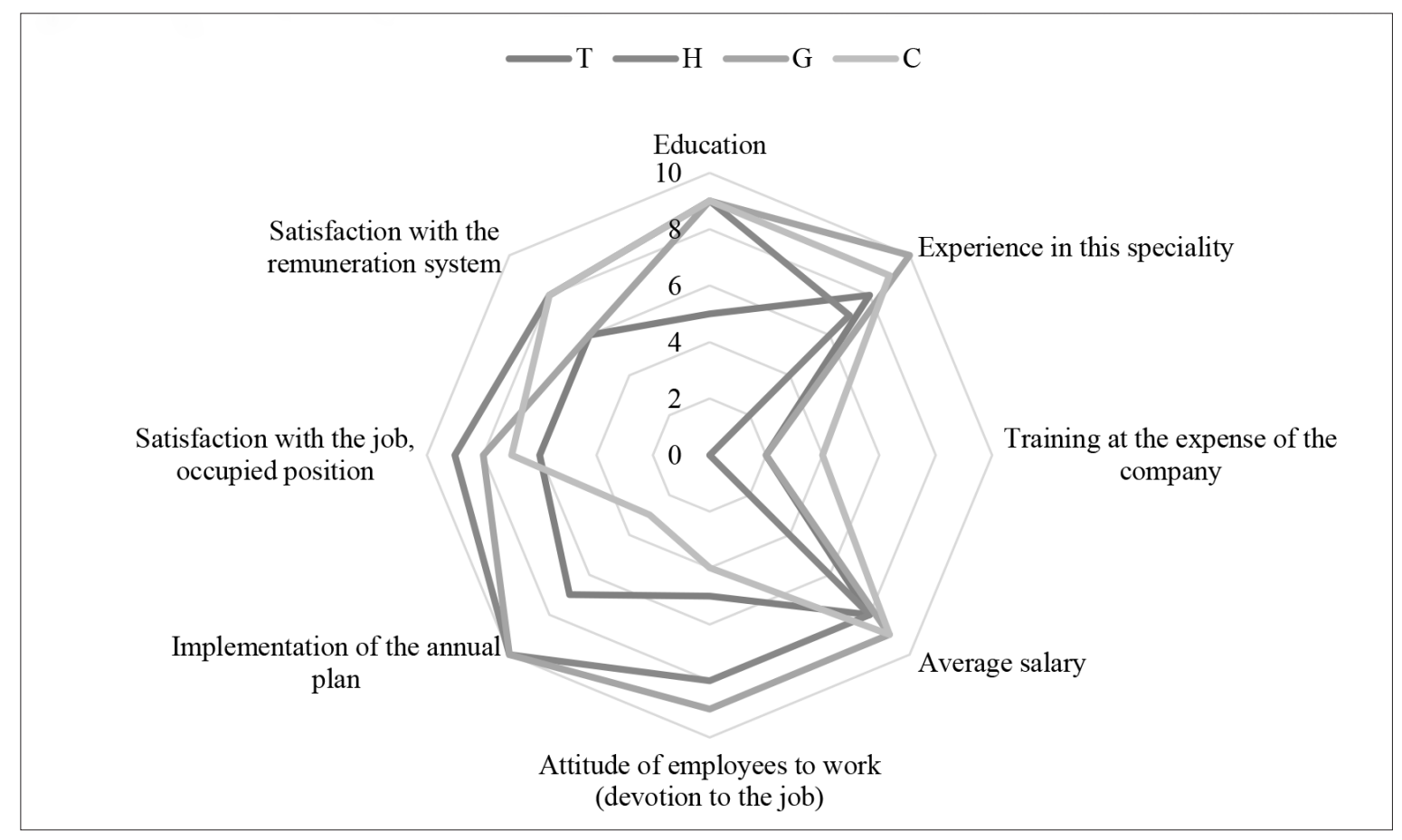

Fig. 1. Quantitative assessment of human capital of Scania AB

Source: Designed by the authors

Everything inside polygons is what the company currently owns; everything beyond its borders is what can be obtained. The radar chart contains a lot of information, but its main value is that it gives a complete picture of intellectual capital. As it was shown by the research in the field of intellectual capital of the company, human capital was the weakest link. The management of Scania AB must pay particular attention to: the education of its employees and their professional improvement; the current system of labor distribution of managers; the development of a new remuneration system and payment of bonuses.

The assessment of national human capital is of great interest in addition to assessing human capital of the company in terms of addressing the challenge of ensuring strategic competitiveness and proper economic security. According to rather widespread representations, the sustainable development of companies largely depends on the competitiveness of the state, which in its turn is strongly influenced by national human capital.

\section{Efficiency of human capital in the system of economic security}

National human capital is significantly different in quality and value per capita, as well as in its efficiency for different countries. These HC indicators depend on the quality and ethics of work, which are historically determined by the level of economic freedom and mentality. The economic freedom of the country is currently measured by the international index of economic freedom, which, in turn, is calculated on 10 complex indicators, which reflect generally the quality of labor, business, and management. 
The correlation between human capital and investments is determined by following expression:

$$
H C=f(j, q, I, X)=c \times I \text {, }
$$

where $j$ is the labor index quality in a broad definition,

$q$ is the quality index of accumulated $\mathrm{HC}$,

$I$ is investments in $\mathrm{HC}$,

$X$ is other variables on which the $\mathrm{HC}$ depends, including the accumulated $\mathrm{HC}$ itself.

The index of investment transformation into human capital $c$ determines numerically the efficiency or productivity of $\mathrm{HC}$. The value of the $\mathrm{HC}$ can be more than 1 (for the most developed countries with the highest quality of $\mathrm{HC}$, with a developed innovative economy, knowledge- and information- based economy, information society) and less than 1 for developing countries and the underdeveloped countries of the world. For countries with poor quality of work and low productivity of LC, $c$ is several times lower than in developed countries, as well as labor productivity (Bordens, 2006).

The index of investment transformation into HC reflects the integral efficiency of HC, which, in turn, determines average labor productivity in industries with high added value and in the production of knowledge (industries with high technologies, scientific products, innovations, new technologies, production of high technologies).

The efficiency of human capital $c$ reflects how many units of $\mathrm{HC}$ can be obtained per unit of investment in a given country. Moreover, the number of these units (numerical value of $c$ ) is determined mainly by the integral efficiency of the accumulated national HC.

The efficiency of accumulated human capital $c$ is defined as follows:

$$
\begin{gathered}
c=0.5 \times(j+q) \times k \\
k=(\mathrm{GDP}-\text { Exports of natural products }) / \mathrm{GDP}
\end{gathered}
$$

where $k$ is the index of raw material economy that reflects the raw material nature of a poorly diversified and backward economy suffering from a "Dutch disease."

GDP and export of natural products are determined at the current exchange rate. Numerical coefficient 0.5 reflects the equality of the specific weight of labor $j$ in its expanded definition and the specific weight of the quality of the accumulated human capital $q$ (Smith, 2006).

The labor index $j$, in its broader definition, reflects economic freedom, including ethics and working conditions, ethics and entrepreneurial conditions, people's mentality, and the effectiveness of state institutions in this direction.

The index $q$ of the accumulated national human capital reflects the efficiency of skilled labor resources, the creative power of the accumulated LC, the indices $j$ and $q$ are included in the calculation of formula with equal weights.

The labor index is defined as follows:

$$
j=T \times L \times B \times P
$$

where $T$ is the index of traditions (mentality);

$L$ is the index of labor quality;

$B$ is the index of business quality;

$P$ is the index of law-abidingness of the population (or its legal nihilism). 
The normalized Index of Economic Freedom (IEF) is widely used in international practice and reflects on the merits and numerically the set of private coefficients of formula (3), as shown by analysis and calculations. Therefore, formula (2) uses the international IEF index in order to simplify calculations, to increase their reliability and representativeness (Residents and social processes 2017).

The Index of Economic Freedom is calculated on the basis of 10 subindices: Freedom of business, Freedom of Trade, Fiscal freedom, Government expenditures, Freedom of prices, Freedom of investment, Freedom of the financial sector, Protection of property rights, Level of corruption and Freedom of Labor Market. All these indicators are correlated to the characteristics and quality of the conditions in the country for work and business, and, therefore, they determine the investment attractiveness of the country.

The value of each indicator varies from 0 to 100 points (100 points means the maximum level of economic freedom). In fact, subindices reflect ethics, quality and productivity (including entrepreneurial, managerial, and intellectual work) and conditions for its free and effective implementation. Therefore, the IEF index is used for calculations in normalized units of the index of economic freedom, which greatly simplifies the calculations (the IEF index is divided by 100).

$$
j=\mathrm{IEF} / 100,
$$

The HC quality index combines the influence of another group of subindices (factors) on the HC efficiency index.

$$
q=\operatorname{lxh} x \text { s } x \text { ixe, }
$$

where $l$ is the index of quality of life of the population of the country,

$h$ is the index of $\mathrm{HC}$ inflow outside of the subject (outflow from it);

$s$ is the index of science and synergetics;

$i$ is the Human Development Index (HDI);

$e$ is the index of the efficiency of the national elite.

Coefficient of HC inflow is equal:

$h=$ (the initial number of scientists, the inflow (- outflow) of scientists) / the initial number of

The index of science and synergetics:

$$
s=(1+10 n+w)
$$

where $n$ is gross domestic investments in science in parts of GDP (in the UNESCO terminology), $w$ is the country's share in total world investment in science.

The index of the efficiency of the national elite:

$$
e=(\mathrm{GDP}-\mathrm{The} \text { shadow economy sector }) / \mathrm{GDP} \text {. }
$$

Thus, indices of international organizations are used in order to calculate the efficiency indexes of HC: Index of Economic Freedom, IEF; index of quality of life of the population (QL); Human Development Index (HDI), as well as index of science and synergetics calculated according to the report of UNESCO for 2018; index of $\mathrm{HC}$ inflow outside of the subject (outflow from it); quality index of accumulated HC (its calculation is made by the group of indicators and indices); index of the efficiency of the national elite and the shadow economy; the index of raw material economy, reflecting the type of mainly raw material economy and the dependence of the country with the industrial raw material economy on the export of raw materials (Zander, and Kogut, 1995). 
Calculations of the $\mathrm{HC}$ efficiency on a large number of indicators reflect the HC quality and efficiency, as well as the average productivity of the country or another entity and the level of its economic security. On the other hand, HDI smoothes out on a small number of calculated indicators (three) and the geometric average difference between them in terms of HC quality and efficiency in the world.

For example, in 2018, HDI amounted to 0.902 in the USA, in Russia - 0.719, and in Ukraine - 0.561 (difference $35 \%$ ). This, of course, does not reflect the gap between countries on human potential and value per capita (and productivity) of national HCs of these countries. The ratio of the indices of the HC efficiency is different: the USA index is 7.1 times higher than the Ukrainian one, which is close to the ratio of average productivity in these countries (Table 4).

Table 4. The index of human capital efficiency in the system of economic security

\begin{tabular}{|c|c|c|c|c|c|}
\hline $\begin{array}{l}\text { 吾 } \\
\text { 己 }\end{array}$ & 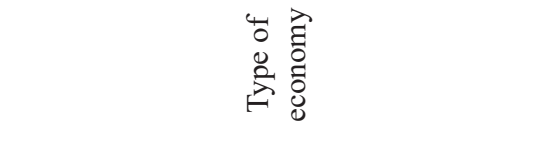 & 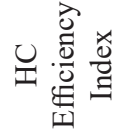 & 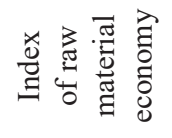 & 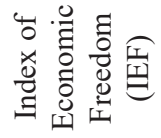 & 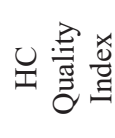 \\
\hline 1 & 2 & 3 & 4 & 5 & 6 \\
\hline USA & Knowledge- and information- based & 1,225 & 1 & 0,78 & 1,67 \\
\hline United Kingdom & Innovative & 0,855 & 1 & 0,75 & 0,96 \\
\hline Germany & Innovative & 0,93 & 1 & 0,72 & 1,14 \\
\hline Japan & Innovative & 0,93 & 1 & 0,73 & 1,13 \\
\hline China & Industrial with elements of innovative one & 0,49 & 1 & 0,52 & 0,45 \\
\hline India & Industrial with elements of innovative one & 0,37 & 1 & 0,55 & 0,19 \\
\hline Russia & Industrial raw material & 0,30 & 0,75 & 0,51 & 0,31 \\
\hline Estonia & Industrial & 0,67 & 1 & 0,75 & 0,59 \\
\hline Kazakhstan & Industrial raw material & 0,29 & 0,75 & 0,56 & 0,62 \\
\hline Ukraine & Industrial raw material & 0,29 & 0,75 & 0,56 & 0,62 \\
\hline
\end{tabular}

Source: Human Development Reports (2018), calculation authors

The main disadvantage of HDI lies in the fact that this index does not reflect the quality of education and GDP per capita. In developed countries, the quality and cost of education are much higher than in poor or developing countries. A significant share of the oil and gas sector of the economy and its revenues is pushed up by the HDI rating, for example, the oil-producing Arab countries. And these countries almost do not involve their national $\mathrm{HC}$ even in oil and gas production. Therefore, a lowering factor is used in order to account for high export earnings, when calculating the efficiency of the national HCs of the countries with raw material economies. It equals, for example, 0.75 for Russia, 0.56 for Kazakhstan, and 0.43 for Ukraine. This index equals 1 for developed and developing countries with a diversified economy.

The level of corruption and the criminalization of national human capital is taken into account through the subindices of all major indices: IEF, QL, the quality index of the elite and the shadow economy, the inflow index of the $\mathrm{HC}$, and others.

The basic reasons of low levels of HC efficiency and quality indices of Russia and Kazakhstan are the raw material nature of the economy and exports, a significant proportion of passive $\mathrm{HC}$ and negative $\mathrm{HC}$ (as a result of low investments in $\mathrm{HC}$, high corruption and criminalization of countries).

The task of developing an algorithm for evaluating the company's readiness for the development of a human capital management system is considered in the work (Throsby, (2010). In this paper, it is proposed to use only two criteria, namely the importance of the problem and the company's ability to solve this particular problem (Table 5) in order to generally assess the determination of the priority and sequence of the first steps of the 
formation of a knowledge management system. In any reasonable sense, such an approach follows the logic of constructing the Mission and Core Competencies (MCC) matrix used in strategic management (Yu, 2014).

According to the experience of using MCC matrix, the importance of the task is recommended to assess from the point of view of ensuring the company's competitiveness, stability of its existence and image.

It is necessary to assess the availability, first of all, of intellectual capital and the sufficiency of material resources in determining the capability to solve problems.

The priority of problem solving is quantified as a product of assessments of the importance and capability (PricewaterhouseCoopers methodology).

Table 5. Criteria for prioritizing tasks

\begin{tabular}{|l|c|c|}
\hline \multicolumn{1}{|c|}{ Question } & General task evaluation & Scale of points \\
\hline How important is this task for the company? & Importance & $\begin{array}{c}1-\text { not important } \\
2-\text { not too important } \\
3-\text { very important }\end{array}$ \\
\hline Is the company capable of solving this problem? & Capability & $\begin{array}{c}1-\text { not capable } \\
2-\text { partially capable } \\
3-\text { capable }\end{array}$ \\
\hline
\end{tabular}

Source: Designed by the authors

A similar approach was used in the work (Laursen, and Foss, 2003) in order to evaluate the company's innovation activity. In order to more accurately and objectively make an assessment, it is suggested not to use two, but three criteria, namely readiness, capability and opportunity.

It is argued that this approach is universal, because it makes it possible to evaluate not only the company's capability to innovate, but also to determine the internal motivation and characteristics of external conditions.

Evaluation criteria can be interpreted as follows:

1. The readiness reflects the desire for innovation, as well as the availability of the necessary resources for it.

2. The capability reflects the features of the object, the presence of certain qualities, experience and specific knowledge.

3. The opportunity reflects the presence of internal conditions for the implementation of innovation activities and external conditions that are favorable to this activity.

Each of the criteria considered is complex.

In this scientific work, it is proposed to use three criteria: capability, opportunity and necessity in order to assess the organization's readiness for the formation of a knowledge management system. Selected criteria have the following interpretation:

1. The capability characterizes the presence and degree of "maturity" of intellectual capital.

2. The opportunity characterizes the presence of all the necessary conditions for the existence of a "knowledge spiral".

3. The necessity characterizes the level of awareness of top management of the importance and priority of work related to the creation of the organization that learns. 


\section{Conclusions}

The analysis of relevant implementation of approaches in order to form and improve the quality of human capital potential of industrial companies makes it possible to draw the following conclusions:

It has been established that the main components of non-material reserves for ensuring long-term sustainable development of companies are creative potential of employees, human capital and motivational type. The use of these reserves makes it possible to obtain the socio-economic effect, consisting of providing a positive psychological climate at the enterprise, increasing the involvement of employees in solving the goals and objectives of the enterprise, optimizing labor costs, increasing the qualification level of employees and increasing the level of economic security.

Based on the integration of approaches to the assessment of human capital and creative potential in the system of sustainable development, a system of criteria for the effective use of internal intangibles has been proposed in order to ensure the competitiveness of the company and to stabilize its economic security.

The characteristics of human capital can be interpreted in the context of use in order to ensure an increase in the rates of sustainable development of companies as follows:

- The readiness reflects the desire for innovation, as well as the availability of the necessary resources for it.

- The capability reflects the features of the object, the presence of certain qualities, experience and specific knowledge.

- The opportunity reflects the presence of internal conditions for the implementation of innovation activities and external conditions that are favorable to this activity.

\section{References}

Ahammad, T. (2017). Personnel Management to Human Resource Management (HRM): How HRM Functions? Journal of Modern Accounting and Auditing, September 13(9): 412-420. https://doi.org/10.17265/1548-6583/2017.09.004

Arribas, I., Espinós-Vañó, M. D., García, F., Tamosiuniene, R. (2019). Negative screening and sustainable portfolio diversification, Entrepreneurship and Sustainability Issues 6(4): 1566-1586. https://doi.org/10.9770/jesi.2019.6.4(2)

Bordens, K. (2006). Research Design \& Methods. New Delhi: Tata McGraw-Hill.

Drobyazko S. (2018a) Personnel management as element of the economic safety system of business. Rocznik Aaministracji publicznej, 2018 (4): 210-218. https://doi.org/10.4467/24497800RAP.18.012.9227

Drobyazko S. (2018b) Formation of competitive positions as providing of economic security of insurance companies // International scientific journal “Internauka”. Series: “Economic Sciences”. №2. URL: https://doi.org/10.25313/2520-2294-2017-2-4784

Hamid, S. N. A., Yahya, K. K. (2011). Relationship Between Person - Job Fit and Person - Organization Fit on Employees' Work Engagement: A Study among Engineers in Semiconductor Companies in Malaysia. Annual conference on Innovations in Business and Management, London, 6-9 June, UK: 1-30.

Human Development Reports (2018). URL: Reports http://hdr.undp.org/en/data

Garfield, S. (2014). Knowledge Management Benefits. URL: https://medium.com/@stangarfield/15-knowledge-management-benefitsfc4c97774784

Grip de, A., Loo van, J. and Sanders, J. (2001). The Industry Employability Index: Taking account of supply and demand characteristics. Research Centre for Education and the Labour Market (ROA), Faculty of Economics and Business Administration, Maastricht University. URL: http://citeseerx.ist.psu.edu/viewdoc/download?doi=10.1.1.199.3518\&rep=rep1\&type=pdf

Korauš, A., Gombár, M., Kelemen, P., Backa, S. (2019). Using quantitative methods to identify insecurity due to unusual business operations. Entrepreneurship and Sustainability Issues 6(3): 1101-1012. http://doi.org/10.9770/jesi.2019.6.3(3)

Kumar, N.S., Haque, M.I., Venugopal, K. 2019. Employment challenges in Saudi Arabia: an attitudinal study. Entrepreneurship and Sustainability Issues, 6(4): 1637-1646. http://doi.org/10.9770/jesi.2019.6.4(6) 
Laursen, K. \& Foss, N. J. (2003). New human resource management practices, complementarities and the impact on motivation performance. Cambridge University of Economics, [Online] 27 (2): 243-263. Available at: http://cje.oxfordjournals.org/content/27/2/243. full.pdf + html

Lee, S. M., \& Hong, S. (2002). An enterprise-wide knowledge management system infrastructure. Industrial Management \& Data Systems, 102(1): 17-25. https://doi.org/10.1108/02635570210414622

Lievens, F., Hoye, G. V., \& Anseel, F. (2007). Organizational identity and employer image: towards a unifying framework. British Journal of Management, 18(s1): S45-S59. http://ink.library.smu.edu.sg/lkcsb_research/565

Makedon V., Hetman O., Yemchuk L., Paranytsia N., Petrovska S. (2019). Human resource management for secure and sustainable development, Journal of security and sustainability issues 8(3): 345-354. http://doi.org/10.9770/jssi.2019.8.3(5)

Macky, K. \& Boxall, P. (2007). The Relationship between "High Performance Work Practices" and Employee Attitudes: an Investigation of Additive and Interaction Effects. The International Journal of Human Resource Management, [Online] 18 (4): $537-567$. Available at: http:/www.tandfonline.com/doi/pdf/10.1080/09585190601178745

Markoulli, M., Lee, C. I., Byington, E., \& Felps, W. A. (2017). Mapping Human Resource Management: Reviewing the field and charting future directions. Human Resource Management Review, 27(3): 367-396. URL: https://www.sciencedirect.com/science/ article/abs/pii/S1053482216300699

Martin, G., \& Hetrick, S. (2006). Corporate reputations, branding and people management: a strategic approach to HR. Amsterdam: Butterworth-Heinemann. URL: https://epdf.tips/corporate-reputations-branding-and-people-management-a-strategic-approach-to-hr. html

Masood, O., Tvaronavičienè, M., Javaria, K. (2019). Impact of oil prices on stock return: evidence from G7 countries. Insights into Regional Development, 1(2): 129-137. https://doi.org/10.9770/ird.2019.1.2(4)

Meyer, J. P., Hecht, T. D., Gill, H., Toplonytsky, L. (2010). Person - Organization fit and employee commitment under conditions of organizational change: a longitudital study, Journal of vocational behavior 76 : 458-473. https://psycnet.apa.org/doi/10.1016/j. jvb.2010.01.001

Mosley, R. (2007). Customer experience, organizational culture and the employer brand. Brand Management, 15(2), 123-134. http:// dx.doi.org/10.1057/palgrave.bm.2550124

Myloni, B., Harzing, A. W. \& Mirza, H. (2006). The effect of corporate level organizational factors on the transfer of Human Resource Management Practices: European and US MNCs and their Greek subsidiaries. The International Journal of Human Resource Management, [Online] 18(12), 2057-2074. Available at: http://www.harzing.com/download/hrmxfer.pdf

Prakash, R., Garg, P. (2019). Comparative assessment of HDI with Composite Development Index (CDI). Insights into Regional Development, 1(1): 58-76. https://doi.org/10.9770/ird.2019.1.1(5)

Residents and social processes (2017). [Electronic resource] // Central Statistical Office website Resource viewed 2017 10 Apr. http:// data.csb.gov.lv/pxweb/lv/Sociala/Sociala_ikgad_iedz_iedzskaits/?tablelist=true\&rxid=09cbdccf-2334-4466-bdf7-0051bad1decd

Sagiyeva, R,, Zhuparova, A., Ruzanov, R., Doszhan, R., Askerov, A. (2018). Intellectual input of development by knowledge-based economy: problems of measuring in countries with developing markets. Entrepreneurship and Sustainability Issues, 6(2): 711-728. http://doi.org/10.9770/jesi.2018.6.2(17)

Schuler, R. S. \& Jackson, S. (2005). A Quarter-Century Review of Human Resource Management in the US: the Growth in importance of the International Perspective. Management Revue, [Online] 16(1), 11-35. Available at: http://webcache.googleusercontent.com/searc h?q=cache:M3aBF23E0KMJ:smlr.rutgers.edu/jackson-quarter-century-review-of-hrm $+\& c d=1 \&$ hl=el\&ct=clnk\&gl=gr

Smith, G. P. (2006). United We Stand. Divided We Fall. Available on the Internet: http://chartcourse.blogspot.com

Štiglic, D. (2017). Towards security through economic policy: a Baldwin's approach, Journal of Security and Sustainability Issues 7(1): 55-65. https://doi.org/10.9770/jssi.2017.7.1(6)

Throsby, D. (2010). The economics of cultural policy. Cambridge: Cambridge University Press http://assets.cambridge. org/97805218/68259/frontmatter/9780521868259_frontmatter.pdf

Yu, K. Y. T. (2014). Person-organization fit effects on organizational attraction: A test of an expectations-based model. Organizational Behavior and Human Decision Processes, 124, 75-94.

Whatishumanresource.com. (2017). The historical background of human resource management. Retrieved from http://www. 
whatishumanresource.com/the-historical-background-of-human-resource-management

William, D. (2016). Knowledge Management System. A model for understanding knowledge systems.

Zander, D., \& Kogut, B. (1995). Knowledge and the speed of the transfer and imitation of organisational capabilities: An empirical test. Organisation Science, 6(1), 76-92. Retrieved from https://www0.gsb.columbia.edu/faculty/bkogut/files/1995_OrgSci_Zander_Kogut. pdf

Zhou, J., Wang, Q., Tsai, S. B., Xue, Y., \& Dong, W. (2017). How to evaluate the job satisfaction of development personnel. IEEE Transactions on Systems, Man, and Cybernetics: Systems, 47(11): 2809-2816. URL: https://ieeexplore.ieee.org/abstract/ document/7398159

\section{Short biographical note about the contributors at the end of the article:}

Nataliya DEMIDOVA, Candidate of Economic Sciences, senior research officer of the Department «Economics and management», Federal State-Funded Educational Institution of Higher Education Don State Technical University

ORCID ID: orcid.org/0000-0002-4562-9430

Olena AKILINA, PhD in Economics, Borys Grinchenko Kyiv University, Ukraine

ORCID ID: orcid.org/0000-0001-9968-4921

Mariya KIRZHETSKA, Candidate of Pedagogical Sciences, Associate Professor of the Department of Management and Military Economy, National Academy of National Guard of Ukraine, Kharkiv, Ukraine

ORCID ID: orcid.org/0000-0002-5695-7843

Volodymyr LAGOVSKYI, Candidate of Economic Sciences, Associate Professor of the Department of Statistics and Mathematic Methods in Economics, State Fiscal Service University of Ukraine, Irpin-city

ORCID: ID: orcid.org/0000-0002-2154-5427

Svetlana BESARAB, Senior Lecturer, Kyiv National Economic University, Ukraine

ORCID ID: orcid.org/0000-0002-7343-899X 